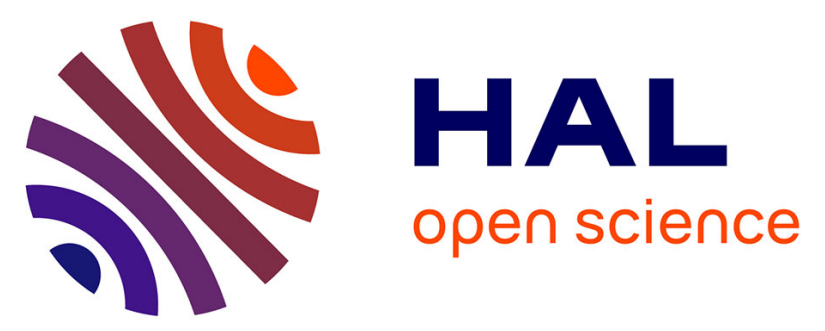

\title{
A numerical model including thermodynamic equilibrium, kinetic control and surface complexation in order to explain cation type effect on chloride binding capability of concrete
}

van Quan Tran, Anthony Soive, Stéphanie Bonnet, Abdelhafid Khelidj

\section{To cite this version:}

van Quan Tran, Anthony Soive, Stéphanie Bonnet, Abdelhafid Khelidj. A numerical model including thermodynamic equilibrium, kinetic control and surface complexation in order to explain cation type effect on chloride binding capability of concrete. Construction and Building Materials, 2018, 191, pp.608 - 618. 10.1016/j.conbuildmat.2018.10.058 . hal-01923534

\section{HAL Id: hal-01923534 \\ https://hal.science/hal-01923534}

Submitted on 26 Nov 2018

HAL is a multi-disciplinary open access archive for the deposit and dissemination of scientific research documents, whether they are published or not. The documents may come from teaching and research institutions in France or abroad, or from public or private research centers.
L'archive ouverte pluridisciplinaire HAL, est destinée au dépôt et à la diffusion de documents scientifiques de niveau recherche, publiés ou non, émanant des établissements d'enseignement et de recherche français ou étrangers, des laboratoires publics ou privés. 


\title{
A numerical model including thermodynamic equilibrium, kinetic control and surface complexation in order to explain cation type effect on chloride binding capability of concrete
}

\author{
Van Quan Tran ${ }^{\mathrm{a}}$, Anthony Soive ${ }^{\mathrm{b}}$, Stéphanie Bonnet ${ }^{\mathrm{c}}$, Abdelhafid Khelidj ${ }^{\mathrm{c}}$ \\ ${ }^{a}$ University of Transport Technology, No. 54 Trieu Khuc street, Thanh Xuan District, \\ Hanoi, Vietnam \\ ${ }^{b}$ Cerema, UMR 7329 GEOAZUR, Pôle d'activités, avenue Albert Einstein CS 70499, \\ 13593 Aix-en-Provence cedex 3, France \\ ${ }^{c}$ Université de Nantes, GeM, Institut de Recherche en Génie civil et Mécanique, CNRS \\ UMR 6183, France
}

\section{Abstract}

The impact of cation type, sulphate and $\mathrm{pH}$ on chloride binding is studied using a numerical model combining thermodynamic equilibrium, kinetics and surface complexation. First, the model is validated by comparing numerical and experimental results obtained on a CEM II concrete material exposed to $\mathrm{NaCl}, \mathrm{KCl}, \mathrm{MgCl}_{2}$ and $\mathrm{CaCl}_{2}$ solutions. Then, the numerical results are discussed to improve our understanding of the differences in chloride binding capability generally observed in the literature. A strong coupling between cation, $\mathrm{pH}$ and sulfate affecting chloride binding is highlighted. After six months of exposure, chloride binding due to Kuzel's salt formation has little effect on chloride binding capability whatever the chloride salt solution. The results also confirm the existence of a relationship between $\mathrm{pH}$ and chloride binding capability previously observed experimentally in the literature. When some sulfate ions are present in the chloride solution, they reduce 
the chloride binding capability because of the sulfate absorption process on C-S-H.

Keywords: Concrete; Chloride binding; Thermodynamic equilibrium;

Kinetic control; Surface complexation; Cation type.

\section{Introduction}

2

Chloride diffusion is one of the major cause of reinforcement corrosion in concrete exposed to seawater or de-icing salts. Many authors consider that corrosion initiation stage of steel reinforcement in concrete depends on the chloride threshold value which can be expressed in a number of different ways, such as: total chloride content in relation to the weight of cement (or concrete) (1), free chloride contents (2), $\left[\mathrm{Cl}^{-}\right] /\left[\mathrm{OH}^{-}\right]$ $(3 ; 4)$. To predict the chloride concentration threshold value in cementitious materials, the performance-based approach Fib model code (5) requires the consideration of the empirical chloride binding isotherm. In this model, based on the analytical solution of the Fick's second law, the chloride binding isotherm is therefore one of the most significant input data of the Fib model code.

A survey of the literature reveals that a considerable amount of effort has been devoted in the last decade to the study of chloride binding in cementitious materials. Page et al. (6), for instance, show that the $\mathrm{OH}^{-}$ concentration (or $\mathrm{pH}$ ) arising from the external environment significantly affects chloride binding. Tritthart (7) and Sandberg et al. (8) both experimentally demonstrate that lower $\mathrm{pH}$ values give higher chloride ions binding, which may be accounted for by a competition among $\mathrm{OH}^{-}$and $\mathrm{Cl}^{-}$ions for 
the sorption sites of hydrated cement (7). Moreover, Roberts (9) and Zhu et al. (10) consider that an increase in pore solution $\mathrm{pH}$ enhances the solubility of chloroaluminate salt (Friedel's salt, Kuzel's salt) consequently reducing chloride binding due to chloroaluminate salt formation.

Furthermore, Arya et al. (11), Page et al. (6), Delagrave et al. (12), Zhu et al. (10), DeWeerdt et al. (13) and Song et al. (14) experimentally observe that cations associated to chloride salts affect chloride binding capability. These authors note that the maximum chloride binding capability is reached when the cementitious materials are exposed to a $\mathrm{CaCl}_{2}$ solution. In a more detailed manner, Zhu et al. (10) and Song et al. (14) experimentally describe that the binding capability of chloride decreases in the order $\mathrm{Ca}^{2+}>\mathrm{Mg}^{2+}$ $>\mathrm{Na}^{+} \approx \mathrm{K}^{+}$when the cementitious samples are exposed to $\mathrm{CaCl}_{2}, \mathrm{MgCl}_{2}$, $\mathrm{NaCl}$ and $\mathrm{KCl}$ solutions, respectively. Wowra et al. (15) find that the $\mathrm{Ca}^{2+}$ cations sorption onto C-S-H surfaces increases the positive charge and in turn the chloride binding in the double electrical layer. Moreover, according to Delagrave et al. (12), the nature of the associated cation significantly affects chloroaluminate solubility and accessibility of chloride ions to sorption sites. On the basis of experimental results, Yuan et al. (16) suggest that, in the presence of $\mathrm{Na}^{+}$, cementitous materials have higher $\mathrm{pH}$ value than with $\mathrm{Ca}^{2+}$ and $\mathrm{Mg}^{2+}$. Zhu et al. (10) demonstrate that $\mathrm{Na}^{+}$and $\mathrm{K}^{+}$may increase the $\mathrm{pH}$ value of pore solutions. These arguments imply that pore solution $\mathrm{pH}$ affects chloride binding capability.

However, DeWeerdt et al. (13) experimentally prove that the relationship between the decrease in pore solution $\mathrm{pH}$ and the increase in chloride binding for exposure solutions like $\mathrm{MgCl}_{2}$ or $\mathrm{CaCl}_{2}$ is not valid when the $\mathrm{SO}_{4}^{2-}$ 
ions concentration is significant. Byfors (17) and Wowra et al. (15) have previously shown that an increase in sulfate ion concentration causes a sharp decrease in chloride binding capability. DeWeerdt et al. (13) suggest that one reason might be the chloride sorption process onto $\mathrm{C}-\mathrm{S}-\mathrm{H}$ and the chloride binding due to the chloroaluminate salt formation capacity. C-S-H indeed, when exposed to $\mathrm{MgSO} 4$ and $\mathrm{MgCl}_{2}$, fixes more $\mathrm{SO}_{4}^{2-}$ ions than $\mathrm{Cl}^{-}$ions, leading to the decreased chloride sorption onto C-S-H. The $\mathrm{SO}_{4}^{2-}$ ions react with the AFm phase to precipitate ettringite which is more stable than the chloroaluminate salts (Friedel's salt, Kuzel's salt) and as a result chloride binding due to chloroaluminate salt formation decreases.

The experimental studies mentioned above emphasize the coupling effect of three different factors affecting chloride binding capability: cation of chloride salt, solution $\mathrm{pH}$ and sulfate concentration. It is, however, interesting to verify and confirm the arguments proposed through a numerical investigation. The numerical study presented in this paper is carried out through the development of a numerical model, its validation through the comparison with the experimental results found in the literature and the analysis of the chloride binding mechanism in a final section.

A number of chloride transport models are found in the literature: some models based on Fick's second law or on the multispecies ionic transport equations (18), (19) and (20), or physically and chemically coupled model (21). These models use global binding isotherms to determine the total chloride amounts as a function of the free chloride amounts. However, isotherms parameters must be calibrated on the basis of experimental data (19).

Numerical models must describe simultaneously chloride sorption and 
binding due to the chloroaluminate salt formation. Chloride sorption can be described using a surface complexation model considering the surface charge and the double electrical layer. Chloride binding due to the chloroaluminate salt formation is described by chloroaluminate precipitation/dissolution using thermodynamic equilibrium and kinetic control. The aim of this paper is to investigate the factors affecting chloride binding in concretes exposed to chloride and other ions. A reactive transport model including thermodynamic equilibrium, kinetic control and surface complexation modelling that has been previously described for chloride ingress and external sulphate attack $(22 ; 23)$ is used.

First, the governing equations used to simulate the reactive transport model in saturated cementitious materials are presented: transport equations, surface complexation describing interaction on mineral surfaces, principle of thermodynamic equilibrium and kinetic laws. Then, the model input data of the model are discussed: parameters of solid species under kinetic constraints, surface complexation parameters, original mineralogical composition of hydrated cement, exposure conditions and numerical procedure, sorption reaction in thermodynamic database. Finally, the modelled results are compared with some experimental data from the literature to validate the numerical model.

\section{Reactive transport modeling and input data}

In this section the reactive transport modeling is exposed on several aspects, such as reactive transport equations, thermodynamic and complexation formation constants and kinetics of dissolution/precipitation. However, 
the description of the model is intentionally reduced since it has been previously published and described in details for chloride transport in concrete (23) and external sulphate attack (22).

\subsection{Reactive transport equations}

The coupling of chemistry and transport in porous media was used to describe the mineral phases evolution in time and space. Toughreact, which is based on integral finite differences method, has been developed for this purpose by solving chemically reactive nonisothermal flows of multiphase fuids in porous media (24). A sequential iterative operator-splitting method is operated to solve the system.

In saturated condition without convection phenomena the main mechanism considered is diffusion which is coupled to chemistry according to the following equation:

$$
\frac{\partial \phi C_{j}}{\partial t}=D_{e} \nabla\left(\nabla C_{j}\right)+q_{j}
$$

where $D_{e}$ is the effective diffusion coefficient of species $j\left(m^{2} . s^{-1}\right)$ which value is the same for all species, $\phi$ the porosity and $C_{j}$ the molar concentration of free species $j$ in a pore solution (mol. $\mathrm{m}^{-3}$ of solution). $q_{j}$ is a source or sink term $\left(\right.$ mol. $\left.m^{-3} . s^{-1}\right)$ that denotes the removing or releasing species $j$ and that is evaluated by chemical calculations. In this study, $q_{j}$ combines sorption onto C- S-H surface (see paragraph 2.4), mineral dissolution/precipitation as explained in paragraphs 2.2 and 2.3 and aqueous complexation in solution.

Porosity can evolve with time by actualizing volume of each mineral species (25) that can precipitate or dissolve. Effective diffusion coefficient 
can also evolve, as follows:

$$
D_{e}^{n+1}=\frac{\phi^{n+1}}{\phi^{n}} D_{e}^{n}
$$

where $n$ labels the number of the time step.

\subsection{Thermodynamic formation constants}

The thermodynamic formation constants of species are taken from CEMDATA07 and Nagra/PSI TDB thermodynamic databases (26). The thermodynamic data are exposed in Table 1. C-S-H is supposed to be a mix of tobermorite $\left(\mathrm{CaO} / \mathrm{SiO}_{2}=0.83\right)$ and jennite $\left(\mathrm{CaO} / \mathrm{SiO}_{2}=1.67\right)$. The Helgeson-Kirham-Flowers (HKF) model (27) is used since it gives accurate activity coefficient with dominance of $\mathrm{NaCl}$ in the solution and when the true ionic strength of the solution is close to 1 (24), as in this study.

At equilibrium, the activity product, $Q_{i}$, of the mineral species $i$ must be equal to its equilibrium constant, $K_{i}$. $Q_{i}$ writes as follows:

$$
Q_{i}=\prod_{j=1}^{N}\left(\gamma_{j} C_{j}\right)^{\nu_{j}}
$$

where $\gamma, C, \nu$ and $N$ are the activity coefficient, the concentration, the stoichiometric coefficient and the number of the ionic species in the reaction, respectively.

\subsection{Mineral dissolution and precipitation kinetics}

Several studies have shown that a pure thermodynamic approach does not seem to be adapted for concrete exposed for several months $(22 ; 23$; $28 ; 29 ; 30)$. Moreover, for $\mathrm{C}-\mathrm{S}-\mathrm{H}$ the reactions can be very slow and even irreversible. 
Table 1: Equilibrium constants of mineral dissolution/precipitation reactions at $25^{\circ} \mathrm{C}$

\begin{tabular}{ll}
\hline Phase reaction & $\log \mathrm{K}_{T_{0}}$ \\
\hline Jennite $+2.33 \mathrm{H}^{+}=1.67 \mathrm{Ca}^{2+}+\mathrm{HSiO}_{3}^{-}+2.76 \mathrm{H}_{2} \mathrm{O}$ & -19.53 \\
Tobermorite $+0.66 \mathrm{H}^{+}=0.83 \mathrm{Ca}^{2+}+\mathrm{HSiO}_{3}^{-}+1.16 \mathrm{H}_{2} \mathrm{O}$ & -0.63 \\
Portlandite $+2 \mathrm{H}^{+}=\mathrm{Ca}^{2+}+2 \mathrm{H}_{2} \mathrm{O}$ & -22.76 \\
Monosulfoaluminate $+12 \mathrm{H}^{+}=4 \mathrm{Ca}^{2+}+2 \mathrm{Al}^{3+}+\mathrm{SO}_{4}^{2-}+18 \mathrm{H}_{2} \mathrm{O}$ & -72.44 \\
Ettringite $+12 \mathrm{H}^{+}=6 \mathrm{Ca}^{2+}+2 \mathrm{Al}^{3+}+3 \mathrm{SO}_{4}^{2-}+38 \mathrm{H}_{2} \mathrm{O}$ & -56.67 \\
Hydrotalcite $+14 \mathrm{H}^{+}=4 \mathrm{Mg}^{2+}+2 \mathrm{Al}^{3+}+17 \mathrm{H}_{2} \mathrm{O}$ & -74.68 \\
Kuzel's salts $+12 \mathrm{H}^{+}=4 \mathrm{Ca}^{2+}+2 \mathrm{Al}^{3+}+0.5 \mathrm{SO}_{4}^{2-}+\mathrm{Cl}^{-}+18 \mathrm{H}_{2} \mathrm{O}$ & -73.24 \\
Brucite+$+2 \mathrm{H}^{+}=\mathrm{Mg}^{2+}+2 \mathrm{H}_{2} \mathrm{O}$ & 17.11 \\
Chrysotile $+4 \mathrm{H}^{+}=3 \mathrm{Mg}^{2+}+2 \mathrm{HSiO}_{3}^{-}+3 \mathrm{H}_{2} \mathrm{O}$ & -13.29 \\
Sepiolite $+2 \mathrm{H}^{+}=4 \mathrm{Mg}^{2+}+6 \mathrm{HiO}_{3}^{-}+5 \mathrm{H}_{2} \mathrm{O}$ & -29.01 \\
\hline
\end{tabular}

In this study, the expression of the kinetic law given by Lasaga et al. is used (31):

$$
r_{i}= \pm k_{i} A_{m s, i}\left|1-\left(\frac{Q_{i}}{K_{i}}\right)\right| \quad i=1, . ., N_{q}
$$

where $r$ indicates dissolution or precipitation (for positive and negative values, respectively), $k$ is the rate constant $\left(m o l \cdot m^{-2} \cdot s^{-1}\right) . A_{m s}$ is the specific reactive surface area $\left(m^{2} \cdot g^{-1}\right)$. More details can be found in $\mathrm{Xu}$ et al. and Steefel et al. $(24 ; 25)$.

Table 2 exposes the kinetic parameters for each mineral species. Data are taken from Baur et al. for Monosulfoaluminate, ettringite and C-S-H (32), from Gali et al. for portlandite (33), from Tambach et al. for hydrotalcite (34) and from Palandri and Kharaka for brucite, gibbsite and chrysolite (35). Kuzel's salt is assumed to react instantaneously because of missing data. It is to note that the simulations are performed on concretes exposed to chlorides during several months that is to say for short exposition 
time compared to concrete service life. The kinetics approach is of interest to know which mineral species is susceptible to precipitate during this transient problem. The precipitation of Kuzel's salt is observed (by the model thanks to the kinetics approach) first and at low chloride concentration, while Friedel's salt is observed later and for greater concentration (36).

Table 2: Parameters describing the kinetics of mineral reactions at $25^{\circ} \mathrm{C}$ where $k$ is the dissolution rate constant $\left(\mathrm{mol} . \mathrm{m}^{-2} . \mathrm{s}^{-1}\right)$ and $A_{m s}$ the mineral specific reactive surface area $\left(m^{2} \cdot g^{-1}\right)$. Precipitation mechanism and associated constants are assumed to be similar to dissolution

\begin{tabular}{llll}
\hline Minerals & $A_{m s}$ & $k$ & Ref \\
\hline Jennite & 41.0 & $2.75 \times 10^{-12}$ & $(32)$ \\
Tobermorite & 41.0 & $2.75 \times 10^{-12}$ & $(32)$ \\
Ettringite & 9.8 & $7.08 \times 10^{-13}$ & $(32)$ \\
Monosulfoaluminate & 5.7 & $6.76 \times 10^{-12}$ & $(32)$ \\
Portlandite & 16.5 & $2.24 \times 10^{-8}$ & $(33)$ \\
Hydrotalcite & 9.8 & $1.00 \times 10^{-09}$ & $(34)$ \\
Kuzel's salt & & Instantaneous & \\
Gibbsite & $9.8 \times 10^{-4}$ & $3.16 \times 10^{-12}$ & $(35)$ \\
Brucite & $9.8 \times 10^{-4}$ & $5.75 \times 10^{-9}$ & $(35)$ \\
Chrysotile & $9.8 \times 10^{-4}$ & $10.0 \times 10^{-12}$ & $(35)$ \\
Sepiolite & & Instantaneous & \\
\hline
\end{tabular}

\subsection{Surface complexation formation constants}

In cementitious materials, physical and chemical reactions between aqueous species and specific surface sites of mineral species can occur. These reactions mostly take place onto C-S-H $(37 ; 38 ; 39)$. When the cementitious materials are exposed to boundary solutions, anions and cations move 
through the material and reactions between the ions and the surface site of C-S-H (silanol $\equiv \mathrm{SiOH}$ ) appears (40). A well-known model which is used in this study is the double diffuse layer model (see (41) for a complete description).

Adsorption of $\mathrm{X}$ ions $\left(\mathrm{Ca}^{2+}, \mathrm{Na}^{+}, \mathrm{K}^{+}, \mathrm{Cl}^{-}\right.$and $\mathrm{SO}_{4}^{2-}$ in the present study) onto the C-S-H surface can be described by the following mass action law:

$$
K_{e q}=\frac{[\equiv S i O H X]}{[\equiv S i O H]\{X\}} \exp \left(\frac{-F \psi_{0}}{R T}\right)
$$

where $K_{e q}$ is the equilibrium constant. $\{X\}$ is the activity of $X$ ions. $\psi_{0}$ is the potential at the surface $(V) . R$ is the molar constant $\left(8.354{\mathrm{~J} . \mathrm{mol}^{-1}}^{-K^{-1}}\right)$ and $T$ is the absolute temperature $(K)$.

The sorption of $\mathrm{Ca}^{2+}, \mathrm{Na}^{+}, \mathrm{K}^{+}, \mathrm{Cl}^{-}$and $\mathrm{SO}_{4}^{2-}$ ions on the C-S-H surface layer have been integrated in the database. They can be represented by sorption reactions (see Table 3 ). The equilibrium constants are taken from (40) for $\mathrm{Na}^{+}, \mathrm{K}^{+}, \mathrm{Cl}^{-}$and $\mathrm{Ca}^{2+}$. That of $\mathrm{SO}_{4}^{2-}$ is supposed to be equal to 8.5. The equilibrium constants for $\mathrm{Na}^{+}$and $\mathrm{K}^{+}$are supposed to depend on $C / S$ ratio of C-S-H whereas those for $\mathrm{Ca}^{2+}$ and $\mathrm{Cl}^{-}$are not. Furthermore, the value of the specific surface site of C-S-H is supposed to be equal to 500 $m^{2} \cdot g^{-1}$ as suggested by Viallis et al. after calibration (37).

\section{Concrete properties}

The studied CEMII concrete is taken from the literature (14). The cement composition and the concrete mix-design are given in Tables 4 and 5, respectively. After a 90-day curing period in saturated limewater at $20 \pm 1^{\circ} \mathrm{C}$, 
Table 3: Equilibrium constants of the surface complexation model.

\begin{tabular}{|c|c|c|}
\hline Equation & $\log K_{T_{0}}$ & Ref \\
\hline$\equiv \mathrm{SiOH} \leftrightarrow \equiv \mathrm{SiO}^{-}+H^{+}$ & -12.7 & $(40)$ \\
\hline \multicolumn{3}{|l|}{ or $\equiv \mathrm{SiOH}+\mathrm{OH}^{-} \leftrightarrow \equiv \mathrm{SiO}^{-}+\mathrm{H}_{2} \mathrm{O}$} \\
\hline$\equiv \mathrm{SiOH}+\mathrm{Ca}^{2+} \leftrightarrow \equiv \mathrm{SiOCa}^{+}+\mathrm{H}^{+}$ & -9.4 & $(40)$ \\
\hline$\equiv \mathrm{SiOH}+\mathrm{Cl}^{-} \leftrightarrow \equiv \mathrm{SiOHCl}^{-}$ & -0.35 & $(40)$ \\
\hline$\equiv \mathrm{SiOH}+\mathrm{Ca}^{2+}+\mathrm{Cl}^{-} \leftrightarrow \equiv \mathrm{SiOCaCl}+\mathrm{H}^{+}$ & -9.8 & $a, b$ \\
\hline$\equiv \mathrm{SiOH}+\mathrm{Ca}^{2+}+\mathrm{SO}^{2-} \leftrightarrow \equiv \mathrm{SiOCaSO}_{4}^{-}+\mathrm{H}^{+}$ & -8.5 & $a, b$ \\
\hline$\equiv \mathrm{SiOH}_{\text {jennite }}+\mathrm{Na}^{+} \leftrightarrow \equiv \mathrm{SiONa}_{\text {jennite }}+H^{+}$ & -13.745 & $(40)$ \\
\hline$\equiv S i O H_{\text {jennite }}+K^{+} \leftrightarrow \equiv S i O K_{\text {jennite }}+H^{+}$ & -13.745 & $(40)$ \\
\hline$\equiv S i O H_{\text {tobermorite }}+\mathrm{Na}^{+} \leftrightarrow \equiv \mathrm{SiON}_{\text {tobermorite }}+\mathrm{H}^{+}$ & -12.656 & $(40)$ \\
\hline$\equiv \mathrm{SiOH}_{\text {tobermorite }}+K^{+} \leftrightarrow \equiv S i O K_{\text {tobermorite }}+H^{+}$ & -12.656 & $(40)$ \\
\hline
\end{tabular}

Specific surface site of C-S-H $A_{c s}=500 \mathrm{~m}^{2} \cdot g^{-1}$ (37)

Sorption density of C-S-H $\Gamma_{C-S-H}=8 \times 10^{-6}$ mol.m ${ }^{-2}$ (42), (43)

${ }^{a}$ : Reaction on the C-S-H surface taken from (44)

${ }^{b}$ : Value of $\log K_{T_{0}}$ considered in the study 
some $\varnothing 100 \mathrm{~mm} \times 50 \mathrm{~mm}$ specimens were drilled out. The side and bottom surfaces of the cylinder specimens were sealed with epoxy resin. An immersion test was conducted to determine the penetration depth of chloride and the chloride binding isotherms in saturated conditions at $20^{\circ} \mathrm{C}$ under laboratory conditions. The concrete properties and experimental data are detailed in Song et al. (14).

Table 4: Chemical composition of cement, expressed as a percentage (\%) (14).

\begin{tabular}{lllllllll}
\hline Composition & $\mathrm{SiO}_{2}$ & $\mathrm{Al}_{2} \mathrm{O}_{3}$ & $\mathrm{Fe}_{2} \mathrm{O}_{3}$ & $\mathrm{CaO}$ & $\mathrm{MgO}$ & $\mathrm{SO}_{3}$ & $\mathrm{Na}_{2} \mathrm{O}$ & $\mathrm{K}_{2} \mathrm{O}$ \\
\hline Content & 21.70 & 5.09 & 4.32 & 64.64 & 0.92 & 1.08 & 0.21 & 0.53 \\
\hline
\end{tabular}

Table 5: Concrete mix-design $\left(\mathrm{kg}^{\mathrm{m}} \mathrm{m}^{-3}\right)(14)$.

\begin{tabular}{lllll}
\hline Cement & Water & Sand & Gravel & w/c \\
\hline 312 & 156 & 746 & 1118 & 0.5 \\
\hline
\end{tabular}

The concrete is supposed to be completely hydrated. Its mineral composition is calculated using the the GEMS-software and CEMDATA07 and Nagra/PSI TDB thermodynamic databases (26). The mineralogical composition is given in Table 6 .

Table 6: Mineralogical content (mol.dm ${ }^{-3}$ of concrete)

\begin{tabular}{ll}
\hline Minerals & Content \\
\hline Jennite & 0.9882 \\
Tobermorite & 0.1384 \\
Ettringite & - \\
Monosulfoaluminate & 0.0421 \\
Portlandite & 1.6011 \\
Hydrotalcite & 0.0178 \\
\hline
\end{tabular}


Assuming that alkalis $N a$ and $K$ are fully dissolved as suggested by Trotignon et al. (45), the initial chemical composition of the pore solution is calculated using the Toughreact software (24) (Table 7).

Table 7: Initial composition of the pore solution in CEMII concrete $\left(m o l . k g^{-1}\right)$ calculated using Toughreact at $20^{\circ} \mathrm{C}$.

\begin{tabular}{ll}
\hline & Concentration $[\mathrm{mol} / \mathrm{kg}$ of pore solution $]$ \\
\hline $\mathrm{Na}^{+}$ & 0.1366 \\
$\mathrm{~K}^{+}$ & 0.2271 \\
$\mathrm{Ca}^{2+}$ & $0.2979 \times 10^{-2}$ \\
$\mathrm{Mg}^{2+}$ & $0.4057 \times 10^{-10}$ \\
$\mathrm{Al}^{3+}$ & $0.2348 \times 10^{-3}$ \\
$\mathrm{HSiO}_{3}^{-}$ & $0.1592 \times 10^{-5}$ \\
$\mathrm{SO}_{4}^{2-}$ & $0.2007 \times 10^{-4}$ \\
\hline $\mathrm{pH}$ & 13.53 \\
\hline
\end{tabular}

\section{Results}

\subsection{Case study description}

CEMII concrete is exposed to four different boundary solutions: 0.5 mol.L $L^{-1} \mathrm{NaCl}$ solution, $0.5 \mathrm{~mol} . \mathrm{L}^{-1} \mathrm{KCl}$ solution, $0.25 \mathrm{~mol} . \mathrm{L}^{-1} \mathrm{MgCl}_{2}$ solution and $0.25 \mathrm{~mol} . \mathrm{L}^{-1} \mathrm{CaCl}_{2}$ solution. In order to investigate the impact of sulfate ions on chloride binding capability, solutions of 0.25 mol. $L^{-1}$ $\mathrm{MgCl}_{2}+0.0276$ mol. $\mathrm{L}^{-1}$ of $\mathrm{MgSO}_{4}\left(\mathrm{SO}_{4}^{2-}\right.$ concentration in seawater $)$ and of 0.25 mol. $L^{-1} \mathrm{MgCl}_{2}+0.276$ mol. $L^{-1}$ of $\mathrm{MgSO}_{4}$, respectively, are simulated. 


\subsection{Numerical procedure}

Only saturated concrete is considered during the simulations. Because the numerical results are compared with experimental data obtained from $\varnothing 100 \mathrm{~mm} \times 50 \mathrm{~mm}$ cylindrical specimens, one-dimensional calculations are carried out. Indeed, during the immersion test, the side and bottom surfaces of the cylinder specimens are sealed with epoxy resin to ensure a onedimensional flow inside the cylinders as the top surface is exposed to the solutions for six months. A simple regular mesh composed of one 1000-element row is used, which represents $100 \mathrm{~mm}$ of the specimens. The reactive transport code Toughreact (24) is used.

In the model proposed here, the only input data used to obtain chloride binding isotherms are the chemical composition of cement and the concrete mix-design. Porosity and effective diffusion data are additionally necessary coefficient when the ion profiles as a function of depth and time are required $(22 ; 30 ; 23)$.

\subsection{Chloride binding isotherms}

Figures 1a,b,c and d display the chloride binding isotherms of concrete after a 6-month exposure to $0.5 \mathrm{~mol} . \mathrm{L}^{-1}$ of $\mathrm{NaCl}, 0.25 \mathrm{~mol} . \mathrm{L}^{-1}$ of $\mathrm{CaCl}_{2}$, $0.5 \mathrm{~mol} . \mathrm{L}^{-1}$ of $\mathrm{KCl}$ and $0.25 \mathrm{~mol} . \mathrm{L}^{-1}$ of $\mathrm{MgCl}_{2}$ solutions, respectively. The numerical chloride binding isotherms obtained are compared with the experimental data previously found in the literature (14).

The equilibrium computation gives a $p H$ of 8.1 for all the chloride solutions. Further details on the $\mathrm{pH}$ calculation are given in (46). The fact that the experimental chloride binding isotherms for each exposed solution are successfully reproduced by the model confirms that the chloride binding 
capability depends on the boundary solution type. The amount of bound chloride ions in concrete exposed to $\mathrm{NaCl}$ and $\mathrm{KCl}$ solutions are equivalent. They are larger for concrete exposed to $\mathrm{CaCl}_{2}$ and $\mathrm{MgCl}_{2}$ solutions. The chloride binding capability as a function of the boundary solution type decreases in the order: $\mathrm{Ca}^{2+}>\mathrm{Mg}^{2+}>\mathrm{Na}^{+} \approx \mathrm{K}^{+}$. This result confirms the findings of Arya et al. (11), Page et al. (6), Delagrave et al. (12), Zhu et al. (10), DeWeerdt et al. (13).
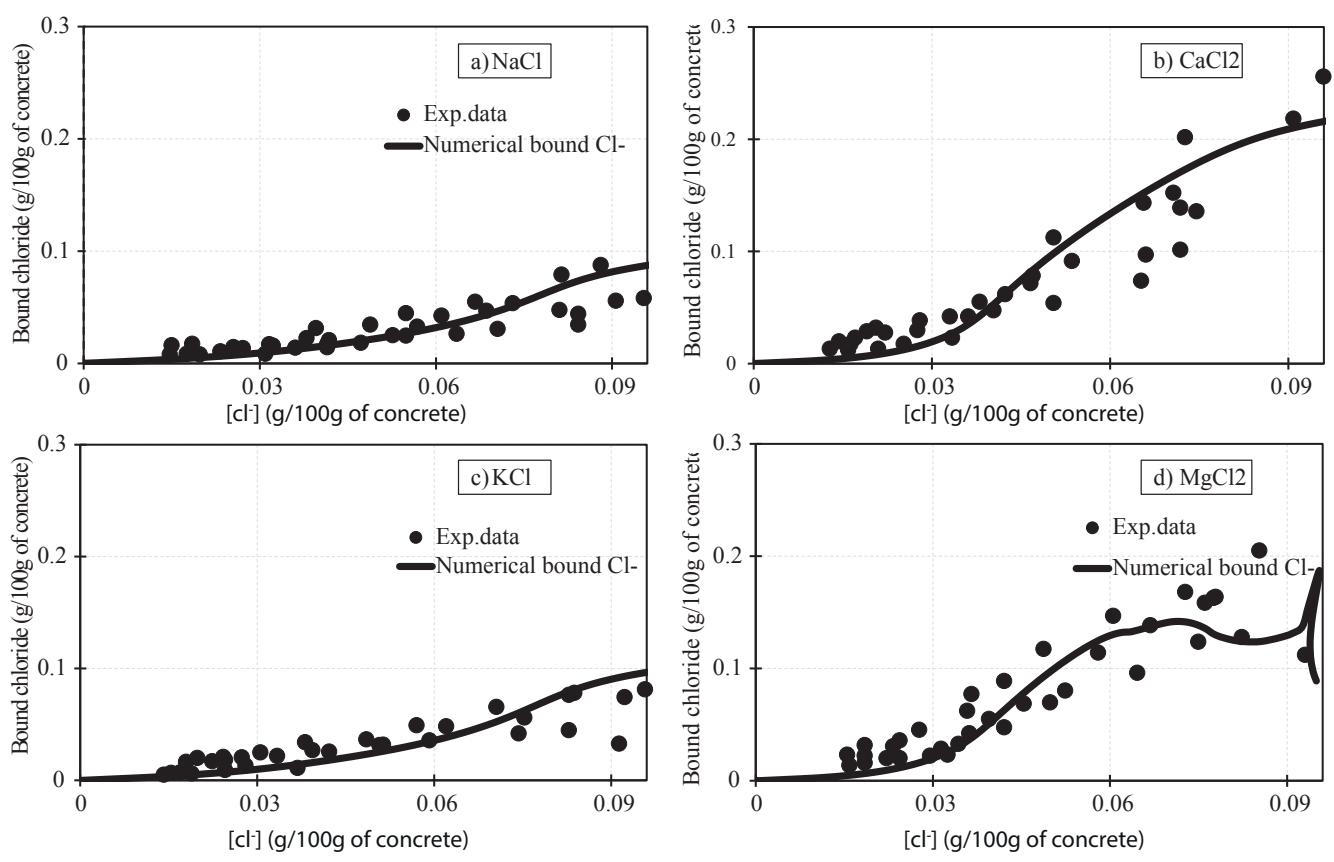

Figure 1: Chloride binding isotherm of CEM II concrete after 3 months of exposure to a) $0.5 \mathrm{~mol} . \mathrm{L}^{-1} \mathrm{NaCl}$ solution, b) $0.25 \mathrm{~mol} . \mathrm{L}^{-1} \mathrm{CaCl}_{2}$ solution, c) $0.5 \mathrm{~mol} . \mathrm{L}^{-1} \mathrm{KCl}$ solution and d) $0.5 \mathrm{~mol} . \mathrm{L}^{-1} \mathrm{MgCl}_{2}$ solution at $20^{\circ} \mathrm{C}$ (experimental data taken from the literature $(14))$. 


\section{Discussion}

As discussed above, the model proposed in this paper can compute chloride absorption on C-S-H, chloride binding due to Kuzel's salt formation and $\mathrm{pH}$ evolution. The following section provides some interpretive elements for a better understanding of the evolution of chloride binding capability as a function of boundary solution type. First, the chloride bound amount due to Kuzel's salts precipitation and to surface complexation on C-S-H is highlighted. Then, the influence of cations associated with chloride from surface complexation on C-S-H and its consequence in terms of $\mathrm{pH}$ is discussed. finally, additionally focus is made on magnesium and sulfate ions and their effect on chloride binding capability.

\subsection{Kuzel's salt formation and surface complexation on $C-S-H$}

Chloride ions can be adsorbed and absorbed on C-S-H. The adsorption on C-S-H are supposed to happen on two C-S-H sites in the proposed model: $\equiv \mathrm{SiOH}$ and $\equiv \mathrm{SiOCa}^{+}$. Chloride ions can also react with monosulfoaluminate to form Kuzel's salts. The numericla results of sorption of chloride ions is shown on Figures 2a, b, c, d for concrete specimens exposed to $\mathrm{NaCl}, \mathrm{CaCl}_{2}, \mathrm{KCl}$ and $\mathrm{MgCl}_{2}$ solutions during six months, respectively.

The results show that the chloride quantity which reacts with $\mathrm{C}-\mathrm{S}-\mathrm{H}$ is always greater than the quantity which reacts to form Kuzel's salts. They also show that Kuzel's salts quantity is the same whatever the boundary solution type, except for the highest chloride concentration when concrete is exposed to a $\mathrm{MgCl}_{2}$ 

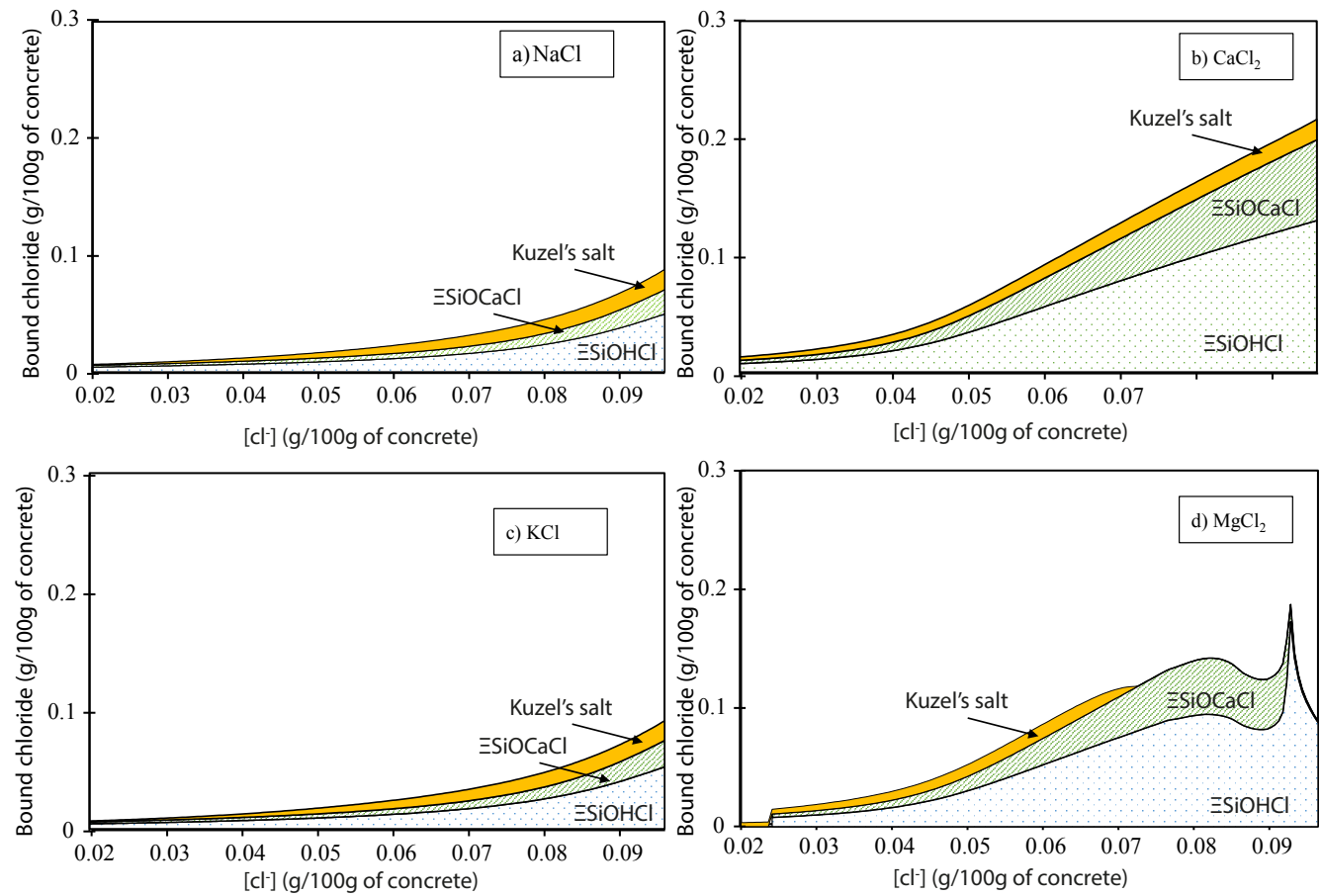

Figure 2: Chloride binding isotherm for CEM II concrete after a 6-month exposure to chloride sorption on C-S-H surface and chloride binding for a) 0.5 mol. $L^{-1} \mathrm{NaCl}$, b) 0.25 mol. $\left.\mathrm{L}^{-1} \mathrm{CaCl}_{2}, \mathrm{c}\right) 0.5 \mathrm{~mol} . \mathrm{L}^{-1} \mathrm{KCl}$ and d) $0.5 \mathrm{~mol} . \mathrm{L}^{-1} \mathrm{MgCl}_{2}$ solutions at $20^{\circ} \mathrm{C}$, respectively. Contribution of Kuzel's salt formation and chloride sorption on C-S-H sites $\left(\equiv \mathrm{SiOHCl} l^{-}, \equiv \mathrm{SiOCaCl}\right)$ 
solution. This latter case is discussed in Section 5.3.

\subsection{Role of cation associated with chloride and $p H$}

According to the chemical equations presented in Table 3, the reactions of the chloride ions bound on $\mathrm{C}-\mathrm{S}-\mathrm{H}$ to form $\equiv \mathrm{SiOHCaCl}$ or $\equiv \mathrm{SiOHCl}-$ are related directly or indirectly to $\mathrm{pH}$. In the first case, the fixation of $\mathrm{Cl}^{-}$and $\mathrm{Ca}^{2+}$ releases $\mathrm{H}^{+}$. In the second case, $\mathrm{Cl}^{-}, \mathrm{Ca}^{2+}$ and $\mathrm{OH}^{-}$are competing in order to react with $\equiv \mathrm{SiOH}$. The reactions with $\mathrm{Ca}^{2+}$ and $\mathrm{OH}^{-}$release $H^{+}$.

Figures $3 \mathrm{a}, \mathrm{b}, \mathrm{c}, \mathrm{d}$ show $\mathrm{Na}^{+}, \mathrm{K}^{+}, \mathrm{Ca}^{2+}$ concentration and $\mathrm{pH}$ profiles as a function of the free chloride concentration after a 6-month exposure, respectively. As expected, $\mathrm{Na}^{+}, \mathrm{K}^{+}$and $\mathrm{Ca}^{2+}$ have the highest concentrations within the concrete pore solutions exposed to $\mathrm{NaCl}, \mathrm{KCl}$ and $\mathrm{CaCl}_{2}$, respectively. Regarding the other ions that are not present in the boundary solutions, the profiles are equivalent whatever the exposed solution, except $\mathrm{Ca}^{2+}$ in the concrete specimens exposed to the $\mathrm{MgCl}_{2}$ solution (cf. Figure 3c). The role of $M_{g C l}$ is discussed in Section 5.3.

These results reveal that the boundary solution types causing a large amount of $\mathrm{Ca}^{2+}$ in the concrete pore solutions $\left(\mathrm{CaCl}_{2}\right.$ and $\left.\mathrm{MgCl}_{2}\right)$ also lead to a greater amount of bound chloride on C-S-H through the formation of $\equiv \mathrm{SiOCaCl}$ (cf. Figures 3c and 2). According to Le Chatelier's principle, a higher $\mathrm{Ca}^{2+}$ amount increases the number of $\equiv \mathrm{SiOCa}^{+}$and, consequently, leads to an increased positive and to a higher chloride ion amount bound on this surface charge. This is consistent with Wowra et al.'s proposal (15).

Figure $3 \mathrm{~d}$ shows that the pore solution $\mathrm{pH}$ of the concrete specimens exposed to $\mathrm{CaCl}_{2}$ and $\mathrm{MgCl}_{2}$ solutions is lower than in the $\mathrm{NaCl}$ and $\mathrm{KCl}$ 

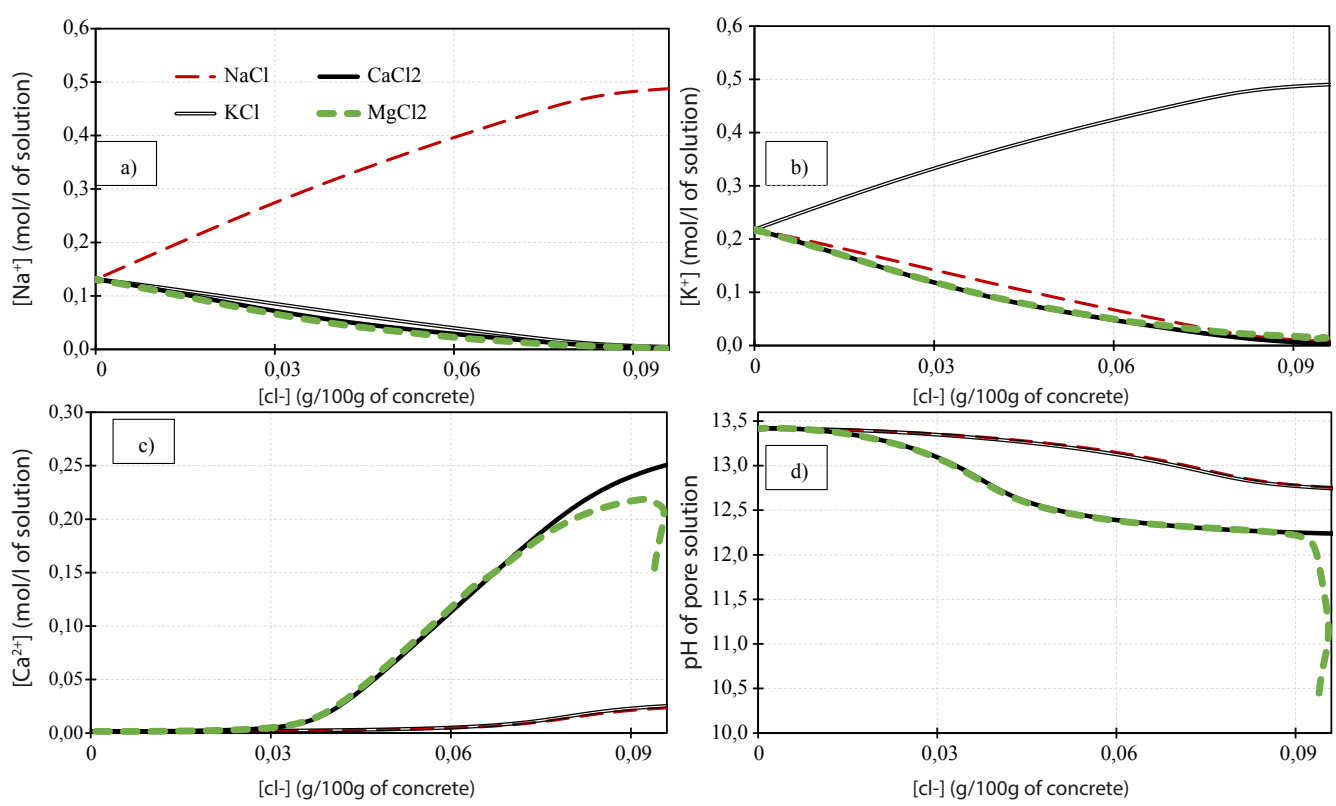

Figure 3: Concentration profile of CEM II concrete after six months of exposure to $\mathrm{NaCl}$, $\mathrm{CaCl}_{2}, \mathrm{KCl}$ and $\mathrm{MgCl}_{2}$ solution at $20^{\circ} \mathrm{C}$ respectively: a) $\mathrm{Na}^{+}$, b) $\mathrm{K}^{+}$, c) $\mathrm{Ca}^{2+}$ and d) $\mathrm{pH}$. 
solutions. This observation implies that the amount of chloride ion reating with C-S-H to form $\equiv \mathrm{SiOHCl}-$ is larger for $\mathrm{CaCl}_{2}$ and $\mathrm{MgCl}_{2}$ solutions than for $\mathrm{NaCl}$ and $\mathrm{KCl}$ solutions (cf. Figure 2). This proves that the $\mathrm{pH}-$ chloride binding capability relationship experimentally observed in $(7 ; 8)$ is verified by the model. Indeed, the higher the $\mathrm{OH}^{-}$concentration (higher $\mathrm{pH})$ in pore solution is, the larger the number of $\equiv \mathrm{SiOH}$ transformed into $\equiv \mathrm{SiO}^{-}$according to Le Chatelier's principle. Then, the amount of $\equiv \mathrm{SiOH}$ decreases and chloride binding capability on C-S-H decreases. This confirms $\mathrm{OH}^{-}$and $\mathrm{Cl}^{-}$competing for sorption on C-S-H.

In conclusion, the pore solution $\mathrm{pH}$ value directly affects chloride binding capability. It depends on the solid/pore solution equilibrium like portlandite dissolution/precipitation and $\mathrm{Na}^{+}$and $\mathrm{K}^{+}$concentrations. In all the cases studied, the Portlandite dissolution is numerically observed (cf. Figure 4). This is less pronounced for concrete exposed to the $\mathrm{CaCl}_{2}$ solution because of higher $\mathrm{Ca}^{2+}$ concentrations. Nevertheless, the $\mathrm{pH}$ value is smaller. It may seem paradoxical considering the fact that the stronger the Portlandite dissolution, the higher the $\mathrm{pH}$, but, because $\mathrm{Na}^{+}$and $\mathrm{K}^{+}$are stronger bases in the acid-base theory than $\mathrm{Ca}^{2+}$ and $\mathrm{Mg}^{2+}$, the pore solution $\mathrm{pH}$ of the concrete exposed to $\mathrm{NaCl}$ and $\mathrm{KCl}$ solutions is higher than with the $\mathrm{CaCl}_{2}$ and $\mathrm{MgCl}_{2}$ solutions.

\subsection{Role of magnesium}

Figure 1 shows that the chloride binding isotherm with the $\mathrm{MgCl}_{2}$ solution behaves differently from the other solutions. With the $\mathrm{MgCl}_{2}$ solution, a peak correspond with chloride binding capability appears for a chloride concentration slightly lower than the maximal value, i.e. within the concrete. In 


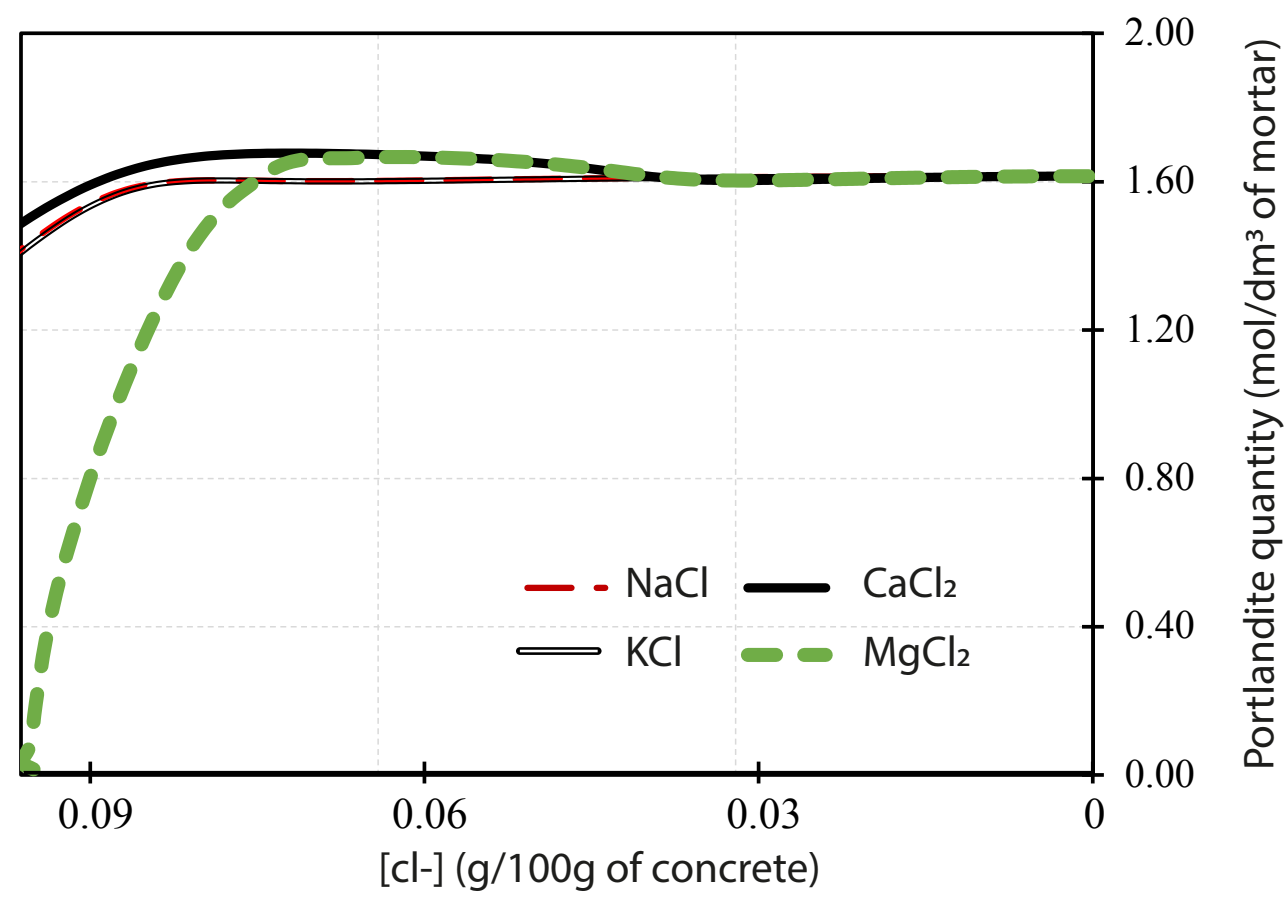

Figure 4: Portlandite amount as a function of depth for concrete specimens exposed to $\mathrm{NaCl}, \mathrm{KCl}, \mathrm{CaCl}_{2}$ and $\mathrm{MgCl}_{2}$ solutions after a 6-month exposure, respectively. 
the meantime, the chloride binding capability is maximum on the concrete surface exposed to $\mathrm{NaCl}, \mathrm{KCl}$ and $\mathrm{CaCl}_{2}$ solutions.

The previous section demonstrates the relationship between chloride binding capability and $\mathrm{Ca}^{2+}$ concentration and $\mathrm{pH}$ value, whereas Figure 2c shows that the $\mathrm{Ca}^{2+}$ concentration in concrete decreases gradually from the exposed surface towards the interior after a 6-month exposure. Moreover, the pore solution $\mathrm{pH}$ on the surface with $\mathrm{MgCl}_{2}$ exposure is the lowest of the four solutions (cf. Figure 2d). An increased $M g^{2+}$ concentration in the exposed solution indeed disturbs portlandite equilibrium and leads to the precipitation of brucite (cf. Figure 5). C-S-H (jennite and tobermorite) is also dissolved and release $\mathrm{HSiO}_{3}^{-}$, which reacts with $\mathrm{Mg}^{2+}$ to precipitate chrysotile. The numerical observation of brucite and M-S-H (chrysotile) formation is experimentally verified $(47 ; 48 ; 49)$. C-S-H and portlandite dissolution also release a large amount of $\mathrm{Ca}^{2+}$ into the pore solutions. The complete dissolution of Portlandite strongly affects the $\mathrm{pH}$ buffering system. Consequently, with such low pH close to the exposed surface, chloride binding capability increases. However, the C-S-H dissolution causes a decrease in the number of surface charges $\equiv \mathrm{SiOHCl}^{-}$, which reduces the ions binding capability of C-S-H on the exposed surfaces.

Furthermore, $\mathrm{Mg}^{2+}$, which progresses within the concrete reacts with $\mathrm{Al}^{+3}$ coming from the monosulfoaluminate dissolution and precipitates hydrotalcite. As a result, the $\mathrm{Al}^{+3}$ concentration is no longer sufficient to precipitate Kuzel's salt despite the high chloride concentration or ettringite found just below the exposed surface. After a period of increase in the hydrotalcite amount, a small amount of ettringite and Kuzel's salt appears (cf. 


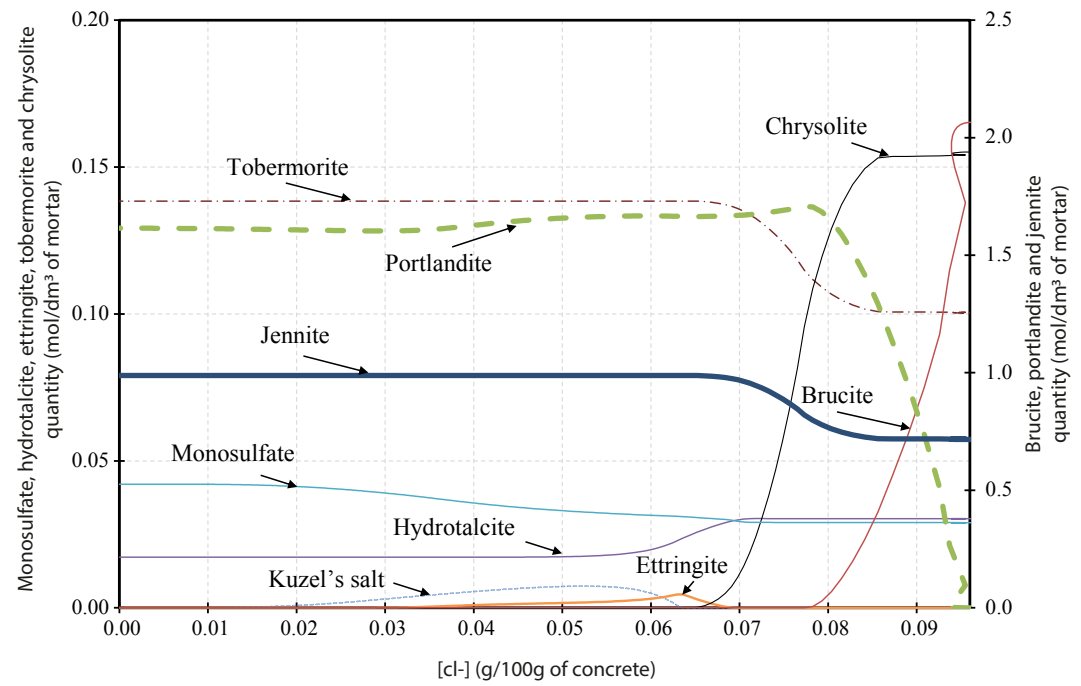

Figure 5: Mineral amount of CEM II concrete after six months of exposure in $\mathrm{MgCl}_{2}$ solution at $20^{\circ} \mathrm{C}$.

Figure 5). Hydrotalcite, ettringite and Kuzel's salt precipitation may be in competition with each other with high magnesium concentration.

For concrete specimens exposed to a $\mathrm{MgCl}_{2}$ solution, $\mathrm{Ca}^{2+}$ leaching reduces the $\mathrm{pH}$ value and, in turn, chloride binding on $\equiv \mathrm{SiOH}$ increases. This can be considered the most significant impact of the $\mathrm{Mg}^{2+}$ cation on chloride binding capability.

\subsection{Role of sulfate}

Figure 6 displays the comparison between the chloride binding isotherms within concrete specimens exposed to $0.5 \mathrm{M}$ of $\mathrm{MgCl}_{2}$ solutions containing 0, 0.0276 $\mathrm{M}$ of $\mathrm{MgSO}_{4}$ and $0.2760 \mathrm{M}$ of $\mathrm{MgSO}_{4}$, respectively. The chloride binding capability is different depending on the concentration in the solution. In other words, the numerical results show that the higher $\mathrm{SO}_{4}^{-2}$ the 
concentration, the weaker the chloride binding capability.

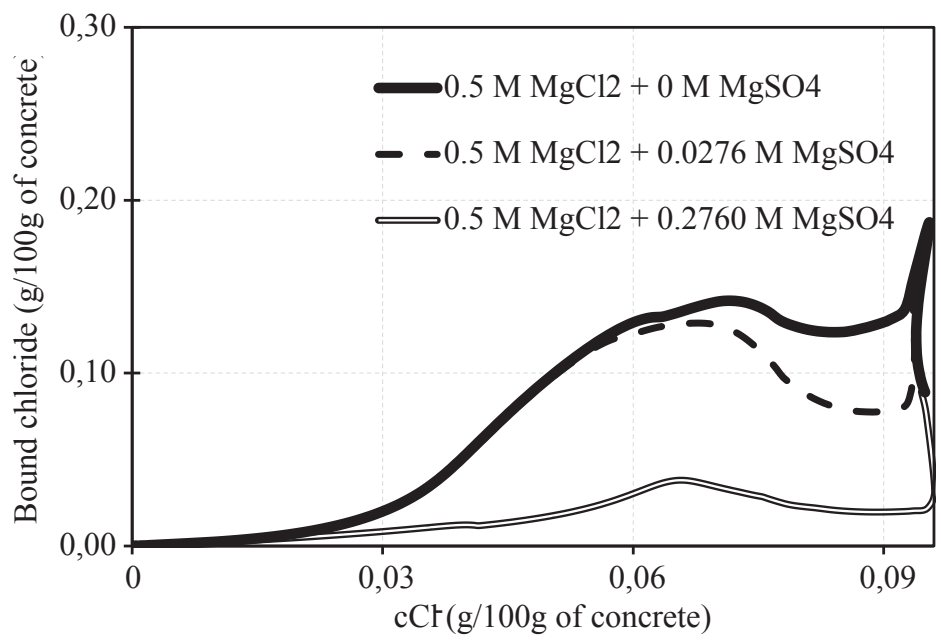

Figure 6: Chloride binding capability after six months of exposure in $0.5 \mathrm{M} \mathrm{MgCl}_{2}, 0.5$ $\mathrm{M} \mathrm{MgCl} l_{2}+0.0276 \mathrm{M} \mathrm{MgSO}_{4}$ and $0.5 \mathrm{M} \mathrm{MgCl}_{2}+0.2760 \mathrm{M} \mathrm{MgSO}_{4}$ solution at $20^{\circ} \mathrm{C}$, respectively.

This can be explained by the fact that the higher the $\mathrm{MgSO}_{4}$ amount, the lower the $\mathrm{pH}$ value (cf. Figure 7a). A comparison between the results obtained with concrete specimens exposed to $\mathrm{MgCl}_{2}$ solutions without $\mathrm{MgSO}_{4}$ and with $0.276 \mathrm{M}$ of $\mathrm{MgSO}_{4}$ shows this clearly. Another explanation is the number of chloride ions that can be adsorbed on C-S-H, which decreases as the amount of $\mathrm{MgSO}_{4}$ increases, under all surface charge conditions: $\equiv \mathrm{SiOHCl}^{-}$or $\equiv \mathrm{SiOCaCl}$ (cf. Figures $7 \mathrm{~b}$ and c). The same tendency is also observed as regards Kuzel's salt formation (cf. Figure 7d).

However, Figure 8 shows that a large amount of sulfate is absorbed on the surface charge $\equiv \mathrm{SiOH}$. Thus, a more negative surface charge $\equiv \mathrm{SiOCaSO}_{4}^{-}$ for the $0.5 \mathrm{M} \mathrm{MgCl}_{2}+0.2760 \mathrm{M} \mathrm{MgSO}_{4}$ solution is released than the 0.5 $\mathrm{M} \mathrm{MgCl}_{2}$ solution and the $0.5 \mathrm{M} \mathrm{MgCl}_{2}+0.0276 \mathrm{M} \mathrm{MgSO}_{4}$ solution. In 

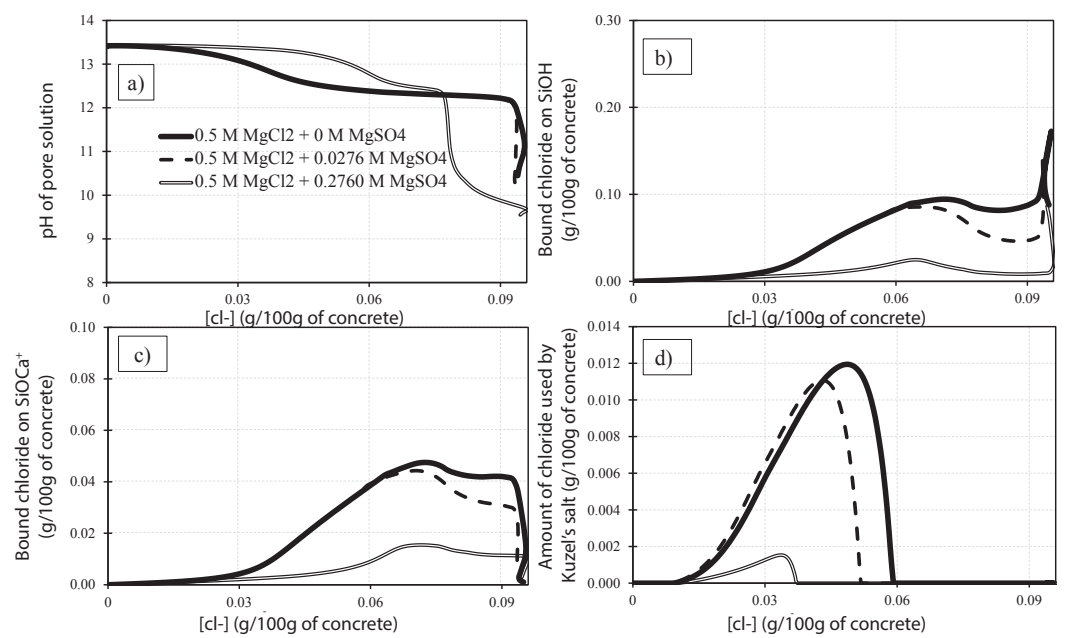

Figure 7: a) Pore solution $\mathrm{pH}$ and chloride binding on b) $\equiv \mathrm{SiOH}, \mathrm{c}) \equiv \mathrm{SiOCa}^{+}$, d) Kuzel's salt formation after six months of exposure in $0.5 \mathrm{M} \mathrm{MgCl}$, $0.5 \mathrm{M} \mathrm{MgCl}_{2}+$ $0.0276 \mathrm{M} \mathrm{MgSO} 4$ and $0.5 \mathrm{M} \mathrm{MgCl}_{2}+0.2760 \mathrm{M} \mathrm{MgSO} 4$ solutions at $20^{\circ} \mathrm{C}$, respectively. 
addition, $\mathrm{Cl}^{-}$and $\mathrm{SO}_{4}^{2-}$ start competing for sorption with $\mathrm{Ca}^{2+}$ on $\equiv \mathrm{SiOH}$. Because of the charge balance condition and the competition between chloride and sulfate, the number of negative surface charges $\equiv \mathrm{SiOHCl}^{-}$must decrease. This can only happen if the chloride binding capability decreases when the solution contains a significant amount of $\mathrm{SO}_{4}^{2-}$.

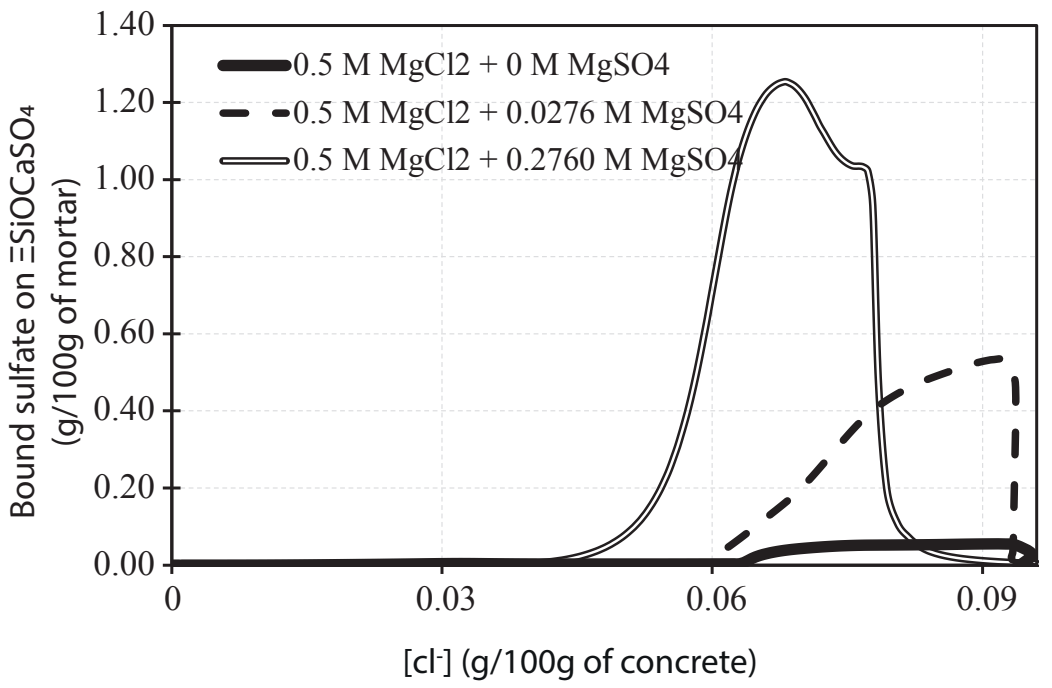

Figure 8: Sulphate binding on $\equiv \mathrm{SiOCaSO}_{4}^{-}$

Chloride binding due to Kuzel's salt formation (cf. Figure 7d) is weakest when $\mathrm{SO}_{4}^{2-}$ concentration is highest. Ettringite formation then occurs at the expense of Kuzel's salt formation as shown in Figure 9. Results are different with the boundary solution without $\mathrm{SO}_{4}^{2-}$. In contrast, the remaining mineral behaviors are similar. Consequently, for the $0.5 \mathrm{M} \mathrm{MgCl}_{2}+0.2760$ M $\mathrm{MgSO} 4$ solution, $\mathrm{Ca}^{2+}$ leaching is not responsible for the low $\mathrm{pH}$. The $\mathrm{pH}$ decrease is essentially due to the presence of $\mathrm{SO}_{4}^{2-}$ and to the adsorption reactions on C-S-H. 


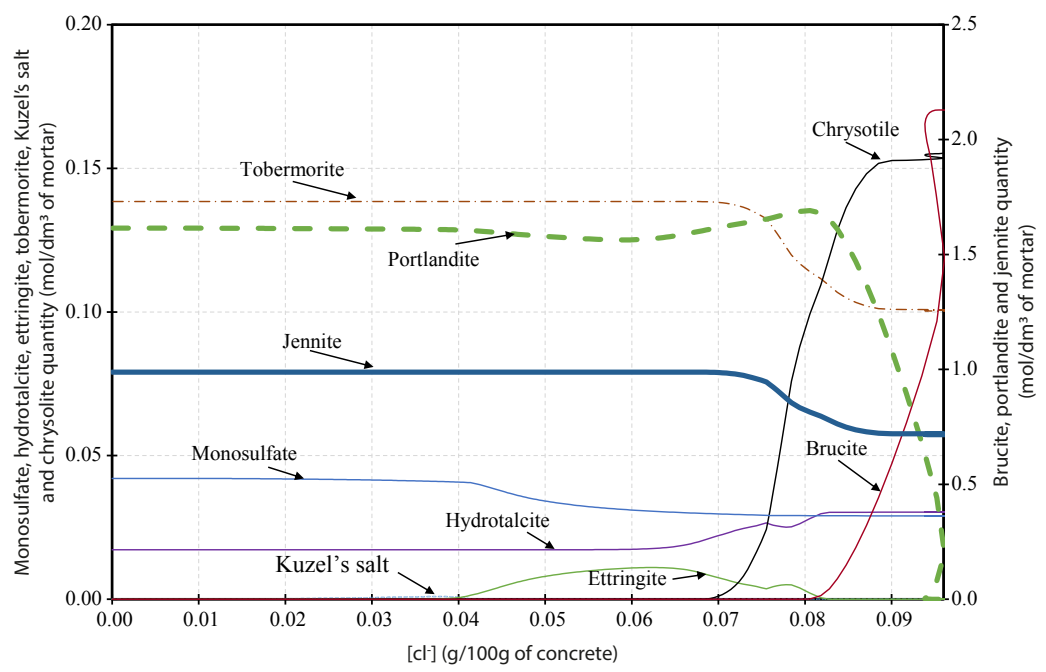

Figure 9: Mineral amount of CEM II concrete after six months of exposure in a $0.5 \mathrm{M}$ $\mathrm{MgCl}_{2}+0.2760 \mathrm{M} \mathrm{MgSO}$ solution at $20^{\circ} \mathrm{C}$.

\section{Conclusion}

In this paper a physically and chemically based multiionic model considering thermodynamical reaction kinetics and surface complexation is proposed to investigate chloride binding capability of CEM II concrete exposed to different boundary chloride solutions. Some chloride binding isotherms from the literature are compared with the numerical results for concrete exposed to $\mathrm{NaCl}, \mathrm{KCl}, \mathrm{CaCl}_{2}, \mathrm{MgCl}_{2}$. The presence of sulfate ions in the $\mathrm{MgCl}_{2}$ boundary solution with two different concentrations is also studied.

The results underline the influence of the cation type associated to the chloride boundary solution on the chloride binding capability. As observed in the literature, the chloride binding capability decreases in the order: $\mathrm{Ca}^{2+}>\mathrm{Mg}^{2+}>\mathrm{Na}^{+} \approx \mathrm{K}^{+}$. In addition, 
the numerical results show that the highest quantity of chloride that reacts is obtained by the sorption on $\equiv \mathrm{SiOH}$, followed by the sorption on $\equiv \mathrm{SiOCa}^{+}$. The chloride ions quantity that reacts to form Kuzel's salts is the smallest one. This latter numerical observation is true whatever the chloride salt solution and the type of cation associated with chloride. As regards the chloride salt solution without sulfate, the competition between $H^{+}$(or indirectly $\mathrm{pH})$ and $\mathrm{Cl}^{-}$onto $\equiv \mathrm{SiOH}$ presents the most significant effect on chloride binding capability. Indeed, the higher the $\mathrm{pH}$ is, the lower the chloride quantity is adsorbed on C-S-H. These conclusions also confirm the relationship between $\mathrm{pH}$ and chloride binding capability observed experimentally in the literature.

This study also shows that the leaching of $\mathrm{Na}^{+}$and $\mathrm{K}^{+}$for the concrete exposed to a $\mathrm{CaCl}_{2}$ solution and the leaching of $\mathrm{Na}^{+}, \mathrm{K}^{+}$and $\mathrm{Ca}^{2+}$ for the concrete exposed to a $\mathrm{MgCl}_{2}$ solution cause a local $\mathrm{pH}$ decrease and, thus, an increase in chloride binding capability. Regarding the $\mathrm{MgCl}_{2}$ solution, the formation of hydrotalcite is enhanced and limits Kuzel's salt precipitation. The higher the $\mathrm{Ca}^{2+}$ concentration is, the higher the chloride amount absorbed on $\equiv \mathrm{SiOCa}^{+}$.

Finally, the model is able to catch that when some sulfate ions are present in the chloride solution, they reduce chloride binding capability because of the sulfate absorption process on C-S-H. A more negatively charged surface $\equiv \mathrm{SiOCaSO}_{4}^{-}$and competition between $\mathrm{Cl}^{-}$and $\mathrm{SO}_{4}^{2-}$ replace $\equiv \mathrm{SiOH}$ in the presence of $\mathrm{Ca}^{2+}$ in the solution. This reaction releases $H^{+}$and decreases the $\mathrm{pH}$. 
These first results have to be confirmed with more experimental data on several concretes and for other ionic species than chlorides although data is missing in the literature. In addition, on the basis of the above study, it could be interesting to explore these findings and study chloride binding capability of concrete exposed to seawater, in which different cations and sulfate ions are present simultaneously.

\section{Acknowledgments}

The present study work is a contribution to the French ANR MODEVIE project. The authors are grateful to the "Agence National de la Recherche" and the Ministries in charge of Sustainable Development, Town Planning and Transportation for their financial support to the project.

\section{Reference}

[1] American Society for Testing and Material, ASTM C-1152. Standard test method for acid-soluble chloride in mortar and concrete.

[2] C. Alonso, C. Andrade, M. Castellote, P. Castro, Chloride threshold values to depassivate reinforcing bars embedded in a standardized $\{\mathrm{OPC}\}$ mortar, Cement and Concrete Research 30 (7) (2000) 1047 - 1055.

[3] D. A. Hausmann, Steel corrosion in concrete. How does it occur?, Materials Protection 6 (1967) 19-23.

[4] V. K. Gouda, Corrosion and corrosion inhibition of reinforcing steel. I. Immersed in alkaline solutions, British Corrosion Journal 5 (1970) 198-203. 
[5] fib, Materials, Wiley-VCH Verlag GmbH \& Co. KGaA, 2013, pp. 74150.

[6] C. L. Page, P. Lambert, P. R. W. Vassie, Investigations of reinforcement corrosion. 1. the pore electrolyte phase in chloride-contaminated concrete, Materials and Structures 24 (4) (1991) 243-252.

[7] J. Tritthart, Chloride binding in cement ii. the influence of the hydroxide concentration in the pore solution of hardened cement paste on chloride binding, Cement and Concrete Research 19 (5) (1989) 683-691.

[8] S. P, L. J (Eds.), Symposium proceedings of Nordic miniseminar on chloride penetration into concrete structures. ,, no. 93, Chalmers University of Technology, Division of Building Materials, 1993.

[9] M. H. Roberts, Effect of calcium chloride on the durability of pretensioned wire in prestressed concrete, Magazine of Concrete Research 14 (42) (1962) 143-154.

[10] Q. Zhu, L. Jiang, Y. Chen, J. Xu, L. Mo, Effect of chloride salt type on chloride binding behavior of concrete, Construction and Building Materials 37 (2012) 512-517.

[11] C. Arya, N. Buenfeld, J. Newman, Factors influencing chloride-binding in concrete, Cement and Concrete Research 20 (2) (1990) 291-300.

[12] A. Delagrave, J. Marchand, J.-P. Ollivier, S. Julien, K. Hazrati, Chloride binding capacity of various hydrated cement paste systems, Advanced Cement Based Materials 6 (1) (1997) 28-35. 
[13] K. D. Weerdt, D. Orsáková, M. Geiker, The impact of sulphate and magnesium on chloride binding in portland cement paste, Cement and Concrete Research 65 (2014) 30-40.

[14] Z. Song, L. Jiang, J. Liu, J. Liu, Influence of cation type on diffusion behavior of chloride ions in concrete, Construction and Building Materials 99 (2015) 150-158.

[15] O. Wowra, M. Setzer, Sorption of chlorides on hydrated cements and c3s pastes, in: M. Setzer, R. Auberg (Eds.), Frost Resistance of Concrete, 1997, pp. 146-153.

[16] Q. Yuan, C. Shi, G. D. Schutter, K. Audenaert, D. Deng, Chloride binding of cement-based materials subjected to external chloride environment-a review, Construction and Building Materials 23 (1) (2009) 1-13.

[17] B. K., Chloride binding in cement paste, Nordic Concrete Research 5 (1986) 27-38.

[18] E. Samson, J. Marchand, K. Snyder, J. Beaudoin, Modeling ion and fluid transport in unsaturated cement systems in isothermal conditions, Cement and Concrete Research 35 (1) (2005) 141 - 153.

[19] V. Baroghel-Bouny, M. Thiéry, X. Wang, Modelling of isothermal coupled moisture-ion transport in cementitious materials, Cement and Concrete Research 41 (8) (2011) 828 - 841.

[20] P. Nguyen, O. Amiri, Study of electrical double layer effect on chloride 
transport in unsaturated concrete, Construction and Building Materials 50 (2014) $492-498$.

[21] E. Samson, J. Marchand, Modeling the effect of temperature on ionic transport in cementitious materials, Cement and Concrete Research 37 (2007) 455-468.

[22] A. Soive, V. Q. Tran, External sulfate attack of cementitious materials: New insights gained through numerical modeling including dissolution/precipitation kinetics and surface complexation, Cement and Concrete Composites 83 (2017) 263-272. doi:10.1016/j.cemconcomp.2017.07.024.

[23] V. Q. Tran, A. Soive, V. Baroghel-Bouny, Modelisation of chloride reactive transport in concrete including thermodynamic equilibrium, kinetic control and surface complexation, Cement and Concrete Research 110 (2018) 70-85. doi:10.1016/j.cemconres.2018.05.007.

[24] T. Xu, N. Spycher, E. Sonnenthal, TOUGHREACT User's Guide: A Simulation Program for Non-isothermal Multiphase Reactive Transport in Variably Saturated Geologic Media, version 2.0, Tech. Rep. October, Lawrence Berkeley National Laboratory (2012).

[25] C. Steefel, C. Appelo, B. Arora, D. Jacques, T. Kalbacher, O. Kolditz, V. Lagneau, P. Lichtner, K. Mayer, J. Meeussen, S. Molins, D. Moulton, H. Shao, J. Šimůnek, N. Spycher, S. Yabusaki, G. Yeh, Reactive transport codes for subsurface environmental simulation, Computational Geosciences 19 (3) (2015) 445-478. 
[26] D. A. Kulik, T. Wagner, S. V. Dmytrieva, G. Kosakowski, F. F. Hingerl, K. V. Chudnenko, U. R. Berner, Gem-selektor geochemical modeling package: revised algorithm and gems3k numerical kernel for coupled simulation codes, Computational Geosciences 17 (1) (2013) 1-24.

URL http://gems.web.psi.ch

[27] H. C. Helgeson, D. H. Kirkham, G. C. Flowers, Theoretical Prediction of the Thermodynamic Behavior of Aqueous Electrolytes by High Pressures and Temperatures, IV; Calculation of Activity Coefficients, Osmotic Coefficients, and Apparent Molal and Standard Relative Partial Molal Properties to 600 Degree (1981).

[28] L. De Windt, P. Devillers, Modeling the degradation of portland cement pastes by biogenic organic acids, Cement and Concrete Research 40 (2010) 1165-1174.

[29] P. Lalan, A. Dauzres, L. De Windt, D. Bartier, J. Sammaljarvi, J.D. Barnichon, I. Techer, V. Detilleux, Impact of a $70 \mathrm{C}$ temperature on an ordinary portland cement paste/claystone interface: an in situ experiment, Cement and Concrete Research 83 (2016) 164-178.

[30] A. Soive, V. Q. Tran, V. Baroghel-bouny, Requirements and possible simplifications for multi-ionic transport models - Case of concrete subjected to wetting-drying cycles in marine environment, Construction and Building Materials (in Press).

[31] A. C. Lasaga, J. M. Soler, J. Ganor, T. E. Burch, K. L. Nagy, Chem- 
ical weathering rate laws and global geochemical cycles, Geochimica et Cosmochimica Acta 58 (10) (1994) 2361 - 2386.

[32] I. Baur, P. Keller, D. Mavrocordatos, B. Wehrli, C. Johnson, Dissolution-precipitation behaviour of ettringite, monosulfate, and calcium silicate hydrate, Cement and Concrete Research 34 (2004) 341-348.

[33] S. Gali, C. Ayora, P. Alfonso, E. Tauler, M. Labrador, Kinetics of dolomite-portlandite reaction: Application to portland cement concrete, Cement and Concrete Research 31 (6) (2001) 933 - 939.

[34] T. J. Tambach, M. Koenen, L. J. Wasch, F. van Bergen, Geochemical evaluation of $\{\mathrm{CO} 2\}$ injection and containment in a depleted gas field, International Journal of Greenhouse Gas Control 32 (2015) 61 - 80.

[35] J. Palandri, Y. Kharaka, A compilation of rate parameters of watermineral interaction kinetics for application to geochemical modeling in us geological survey open file report, Tech. rep., USGS (2004).

[36] A. Mesbah, C. Cau-dit-Coumes, G. Renaudin, F. Frizon, F. Leroux, Uptake of chloride and carbonate ions by calcium monosulfoaluminate hydrate, Cement and Concrete Research 42 (2012) 1157-1165.

[37] H. Viallis-Terrisse, A. Nonat, J. Petit, Zeta-potential study of calcium silicate hydrates interacting with alkaline cations, Journal of Colloid and Interface Science 244 (2001) 58-65.

[38] A. G. Kalinichev*, , R. J. Kirkpatrick, Molecular dynamics modeling of chloride binding to the surfaces of calcium hydroxide, hydrated calcium 
aluminate, and calcium silicate phases, Chemistry of Materials 14 (8) (2002) 3539-3549.

[39] Y. Elakneswaran, T. Nawa, K. Kurumisawa, Electrokinetic potential of hydrated cement in relation to adsorption of chlorides, Cement and Concrete Research 39 (4) (2009) 340 - 344.

[40] Y. Elakneswaran, A. Iwasa, T. Nawa, T. Sato, K. Kurumisawa, Ioncement hydrate interactions govern multi-ionic transport model for cementitious materials, Cement and Concrete Research 40 (12) (2010) $1756-1765$.

[41] D. A. Dzombak, F. M. Morel, Surface complexation modelling : hydrous ferric oxide, A Wiley-Interscience Publication.

[42] S. A. Hamid, The crystal structure of the 11 a natural tobermorite ca2.25[si3o7.5(oh)1.5].1h2o, Zeitschrift fur Kristallographie - Crystalline Materials 154 (1981) 189-198.

[43] C. Labbez, I. Pochard, B. Jonsson, A. Nonat, C-s-h/solution interface: Experimental and monte carlo studies, Cement and Concrete Research 41 (2) (2011) 161-168.

[44] Y. Hosokawa, K. Yamada, B. Johannesson, L. Nilsson, Reproduction of chloride ion bindings in hardened cement paste using thermodynamic equilibrium models, in: 2nd International Symposium on Advances in Concrete Through Science and Engineering, 2006.

[45] L. Trotignon, V. Devallois, H. Peycelon, C. Tiffreau, X. Bourbon, Predicting the long term durability of concrete engineered barriers in a 
geological repository for radioactive waste, Physics and Chemistry of the Earth 32 (2007) 259-274.

[46] V. Q. Tran, The contribution toward understanding of mechanisms of depassivation of steel in concrete exposed to sea water: theory and thermochemical modeling, Ph.D. thesis, Ecole Centrale de Nantes, (in French) (2016).

[47] T. Zhang, C. Cheeseman, L. Vandeperre, Development of low ph cement systems forming magnesium silicate hydrate (m-s-h), Cement and Concrete Research 41 (4) (2011) 439-442.

[48] B. Lothenbach, D. Nied, E. L'Hôpital, G. Achiedo, A. Dauzères, Magnesium and calcium silicate hydrates, Cement and Concrete Research 77 (2015) $60-68$.

[49] U. H. Jakobsen, K. D. Weerdt, M. R. Geiker, Elemental zonation in marine concrete, Cement and Concrete Research 85 (2016) 12 - 27. 